Jurnal Konstruksi Hukum | ISSN: XXXX | E-ISSN: XXXX Vol. 1, No. 2, Oktober 2020, Hal. 296-299| Available online at https://www.ejournal.warmadewa.ac.id/index.php/jukonhum

DOI: https://doi.org/10.22225/jkh.1.2.2567.296-299

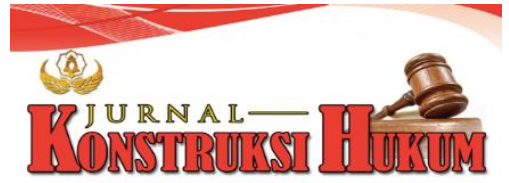

\title{
MEKANISME IMPEACHMENT PRESIDEN DALAM SISTEM KETATANEGARAAN INDONESIA
}

\author{
I Gede Ngurah Bayu Krisna, Gusti Bagus Suryawan, Wayan Arthanaya \\ Fakultas Hukum Universitas Warmadewa, Denpasar-Bali, Indonesia
}

\begin{abstract}
Abstrak
Dalam perjalanan Ketatanegaraan Indonesia telah terjadi pemberhentian presiden sebanyak empat kali dalam masa jabatan. Hal ini menjadi penyebab sengketa antara dua lembaga negara yakni DPR dan Presiden. Namun, setelah reformasi, proses pemberhentian Presiden harus melalui beberapa tahap. Berdasarkan permasalahan itu, penelitian ini bertujuan untuk menganalisi mekanisme impeachment Presiden dalam sistem ketatanegaraan Indonesia dan mengetahui akibat putusan hukum Mahkamah Konstitusi atas permohonan DPR. Penelitian ini menggunakan tipe normatif dengan mencermati UUD NRI tahun 1945 tentang impeachment. Sumber data yang digunakan yaitu UU dan dokumentasi. Kemudian, semua data diolah dan dianalisis dengan argumentasi hukum deduktif-induktif. Hasil penelitian menunjukan bahwa sebelum reformasi, kekuasaan pemerintah sangat besar dan tersentralisasi sehingga melahirkan suatu pemerintahan yang tidak demokratis, serta proses impeachment Presiden menggunakan cara politis daripada alasan yuridis. Namun, pasca era reformasi pengaturan tersebut pun diperjelas dengan perubahan ketiga Undang-Undang Dasar1945 ini melahirkan lembaga baru yakni Mahkamah Konstitusi, otomatis Impeachment pasca reformasi kali ini harus melalui lembaga hukum baru setelah itu lembaga politik.
\end{abstract}

Kata Kunci: Ketatanegaraan; Impeachment; Presiden

\begin{abstract}
In the course of the Indonesian Constitution, the president has been dismissed four times during his term of office. This is the cause of the dispute between the two state institutions, namely the Representative Council (hereinafter referred to as DPR) and the President. However, after reformation, the process of dismissing the President had to go through several stages. Based on these problems, this study aims to analyze the impeachment mechanism of the President in the Indonesian constitutional system and to find out the consequences of the Constitutional Court's legal decisions upon the DPR's request. This research uses the normative type by looking at the 1945 Constitution of the Republic of Indonesia concerning impeachment. The data sources used were law and documentation. Then, all data is processed and analyzed with deductive-inductive legal arguments. The results showed that before the reformation, government power was very large and centralized, giving birth to an undemocratic government, and the impeachment process of the President used political rather than juridical reasons. However, after the reform era, the regulation was made clear by the changes to the three 1945 Constitution that gave birth to a new institution, namely the Constitutional Court, automatically the post-reform Impeachment must go through a new legal institution after that a political institution.
\end{abstract}

Keywords: State Administration; Impeachment; President

\section{PENDAHULUAN}

Negara Republik Indonesia adalah negara yang berbentuk republik dimana dalam melaksanakan kepemerintahannya menggunakan sistem presidensial (Mertokusumo, 2018). Pada dasarnya sistem presidensial didasarkan pada prinsip pembagian kekuasaan, sistem ini banyak dipengaruhi ajaran montesqiu yang terkenal dengan ajaran pemisahan kekuasaannya atau trias politicahal ini bertujuan agar tidak terjadi penyalahgunaan kekuasaan (Diantha, 1998). Penegasan sistem pemerintahan presidensial di Negara Republik Indonesia yaitu:

1. Lembaga Kepresidenan yang mempunyai legitimasi yang kuat dan bercirikan adanya masa jabatan presiden yang bersifat tetap (fixed term).

2. Presiden disamping sebagai kepala negara juga sebagai kepala pemerintahan. 
3. Terciptanya mekanisme saling mengawasi dan saling mengimbangi (checks and balance) dalam sistem pemerintahan saat ini.

4. Adanya mekanisme impeachment.

Selain sebagai konsekuensi logis dianutnya sistem pemerintahan presidensial serta dianutnya ajaran pemisahan kekuasaan dengan mekanisme checks and balance dan perubahan Undang-Undang Dasar 1945, berdampak besar terhadap terjadinya pembentukan, perubahan serta pembaruan lembagalembaga negara salah satunya presiden (Manan, 2003).

Presiden adalah seorang pemegang kekuasaan tertinggi di lembaga eksekutif yang didampingi oleh Wakil Presiden serta dibantu oleh menteri-menteri dalam sebuah kabinet untuk melaksanakan tugastugas pemerintah sehari-hari yang dimana tugas dan kewenangannya sudah tertuang oleh UndangUndang, lantas timbul pertanyaan bagimana jika Presiden/Wakil Presiden melakukan pelanggaran hukum sesuai dengan ketentuan pasal $7 \mathrm{a}$.

Konsekuensi dari pasal 7a memiliki pengaruh terhadap kedudukan serta kewenangan presiden dan/wakil presiden di Indonesia. Karena Indonesia menganut prinsip negara hukum sehingga proses impeachment haruslah melalui proses forum preveliegiatum, yang mana Presiden tidak bisa diberhentikan pada masa jabatannya karena alasan politis semata seperti yang terjadi pada masa mantan presiden Soekarno dan KH Abdul Rahman Wahid.

Jika memang benar Presiden/Wakil Presiden telah melakukan pelanggaran hukum, maka proses selanjutnya terhadap Presiden/Wakil Presiden yang dituduh melakukan pelanggaran hukum adalah impeachment, dan tentunya lembaga yang berhak melakukan impeachment terhadap Presiden/Wakil Presiden merupakan lembaga negara yang sudah diatur dalam Undang-Undang Dasar Negara Republik Indonesia 1945 sesuai ketentuan Pasal 7B.

Proses mekanisme impeachment Presiden yang diatur dalam Pasal 7B UUD 1945 belum pernah dipraktekan dalam kehidupan ketatanegaraan pasca amandemen, tentu hal ini menjadi masalah yang sangat serius, misalnya saja yang menjadi permasalahan apa Presiden dapat diberhentikan oleh parlemen sebelum ada putusan pengadilan umum yang menyatakan presiden telah melakukan pelanggaran hukum atau harus menunggu selesai periode jabatannya baru diadili.

Berdasarkan pengalaman perjalanan sejarah Ketatanegaraan Indonesia dimana telah terjadi pemberhentian Presiden sebanyak dua kali yakni Soekarno dan Abdurahman Wahid. Mengapa impeachment menjadi hal yang amat penting untuk dibicarakan dalam kehidupan ketatanegaraan Indonesia baik dari aspek politik maupun aspek hukum, jawaban tersebut sangatlah sederhana, karena dalam memberhentikan Presiden merupakan hal yang sangat luar biasa dalam hal bernegara. Tentu, dalam proses memberhentikan Presiden terdapat dua lembaga yang berperan yakni lembaga politik DPR dan MPR serta proses hukum di Mahkamah Konstitusi. Oleh karena itu, berdasarkan latar belakang diatas, penelitian baru ini bertujuan untuk menganalisis mekanisme impeachment Presiden dalam sistem Ketatanegaraan Indonesia dan memgetahui akibat putusan hukum Mahkamah Konstitusi atas permohonan DPR.

\section{METODE PENELITIAN}

Penelitian ini dilakukan dengan menggunakan penelitian hukum normatif atau kepustakaan dengan didasarkan pada peraturan perundang-undangan yang terkait dengan Undang-Undang Dasar Negara Republik Indonesia Tahun 1945 tentang Impeachment. Pendekatan yang ditekankan adalah pendekatan tekstual dan kepustakaan tertulis berasal dari referensi yang valid, dan pendekatan kasus, yaitu menganalisa kasus hukum yang terkait dengan bahan-bahan penelitian, sehingga dapat dicocokan antara yang terdapat ditekstual atau kepustakaan dengan kontekstual yang terdapat dalam kasus. Adapun bahan hukum yang digunakan dalam penelitian ini yaitu berupa:

a. Bahan hukum primer seperti UUD Negara Republik Indonesia Tahun 1945, UU No 24 Tahun 2003 Tentang Mahkamah Konstitusi, UU No 17 tahun 2014 (UUMD3)

b. Bahan Hukum Sekunder berupa literatur-literatur hukum perundang-undangan dan dokumendokumen yang berhubungan dengan permasalahan yang dibahas.

Teknik pengumpulan bahan hukum di mulai dengan menginventarisir peraturan perundang-undangan, mengutip, meringkas dan memberikan ulasan-ulasan terkait dengan permasalahan yang dibahas. Setelah bahan hukum diperoleh dan dikumpulkan, bahan hukum kemudian diolah dan dianalisis dengan argumentasi hukum berdasarkan logika hukum deduktif-induktif selanjutnya dituangkan secara 
deskriptif dalam bentuk skripsi yang nantinya akan menghasilkan kesimpulan yang logis terhadap permasalahan yang dibahas.

\section{HASIL DAN PEMBAHASAN}

Mekanisme Impeachment Presiden dalam Sistem Ketatanegaraan Indonesia

Di belahan dunia manapun posisi Presiden sangatlah penting untuk menentukan perjalanan suatu negara, termasuk kehidupan ketatanegaraannya. Hal ini membuktikan bahwa kekuasaan Presiden secara konstitusional diperoleh berdasarkan konstitusi, serta kedudukan Presiden yang bersifat strategis dan tidak boleh lowong sedikitpun. Karena dalam sistem ketatanegaraan Indonesia menganut asas kedaulatan rakyat sesuai Pasal 1 Ayat 2, yang menyatakan bahwa presiden dipilih langsung oleh rakyat pada saat pemilihan presiden, akan tetapi sebelum reformasi terjadinya otoritarianisme pada kehidupan bernegara dan terjadinya sentralisasi kekuasaan serta menyebabkan masalah dalam kehidupan ketatanegaraan dan politik akibatnya Presiden sebelum perubahan Undang-Undang 1945 ialah mandataris MPR yang tunduk dan bertanggung jawab pada majelis tersebut (Darmodiharjo, 1985).

Kekuasaan Presiden secara derivatif diperoleh melalui pelimpahan kekuasaan dalam bentuk pemberian kuasa, serta proses permintaan pertanggungjawaban Presiden sebelum amandemen UndangUndang 1945, sangat terkait pada berbagai aturan yang telah disepakati di tingkat Majelis Permusyawaratan Rakyat. Apabila Presiden dianggap melanggar haluan negara oleh Dewan Perwakilan Rakyat (Soimin, 2009). Maksud dianggap melanggar haluan negara pun tidak jelas yang dimaksud oleh MPR dan DPR, namun dari ketatapan Majelis Permusyawaratan Rakyat yang ada serta di dalam praktek ketatanegaraan Indonesia, pelanggaran terhadap haluan negara adalah pelanggaran terhadap ketetapanketetapan Majelis Permusyawaratan Rakyat baik ketetapan MPR mengenai GBHN serta pelanggaran terhadap Undang Undang Dasar dan Undang-Undang Dasar Tahun 1945, dimana sebelum amandemen Undang-Undang Dasar 1945 proses npemberhentian Presiden dalam masa jabatannya tidak diatur secara tegas baik alasannya maupun mekanismenya. Akan tetapi, yang kita ketahui bersama prosesnya adalah Dewan Perwakilan Rakyat berhak mengawasi tindakan-tindakan Presiden dalam rangka melaksanakan haluan negara, lalu apabila Dewan Perwakilan Rakyat menganggap bahwa Presiden telah melanggar haluan negara maka Dewan Perwakilan Rakyat akan menindak lanjuti dengan cara menyampaikan memorandum untuk mengingatkan Presiden, apabila dalam waktu tiga bulan memorandum tersebut tidak diperhatikan oleh Presiden maka Dewan Perwakilan Rakyat akan menyampaikan memorandum kedua, dan dalam memorandum kedua tersebut tidak diindahkan oleh Presiden, maka Dewan Perwakilan Rakyat akan meminta Majelis Permusyawaratan Rakyat untuk melakukan sidang istimewa untuk meminta pertanggung jawaban Presiden (Anwar, 1999).

Setelah amandemen Undang-Undang Dasar Tahun 1945 yang berkaitan langsung dengan kekuasaan Presiden dan Wakil Presiden dimana hasil perubahan tersebut menghasilkan struktur fondasi yang terbaru dalam kehidupan ketatanegaraan Indonesia dimana Presiden tidak lagi dipilih oleh MPR (Zoelva, 2005: 89-91). Serta Undang-Undang Dasar Negara Republik Indonesia tahun 1945 setelah amandemen pun mengatur alasan-alasan dan mekanisme pemberhentian presiden dalam masa jabatannya seperti:

- Pengkhianatan Terhadap Negara

- Korupsi dan Penyuapan

- Tindak Pidana Berat Lainnya Serta Perbuatan Tercela

- Tidak lagi memenuhi syarat sebagai Presiden dan/ Wakil Presiden

Lalu proses yuridis di Mahkamah Konstitusi dapat dapat dilihat sebagai berikut:

1. Pendaftaran pemohon dalam hal ini Dewan Perwakilan Rakyat di kepaniteraan Mahkamah Konstitusi harus memenuhi ketentuan tentang kedudukan hukum pemohon, kewenangan Mahkamah Konstitusi untuk mengadili, dan pokok perkara disertai bukti-bukti

2. Rapat Permusyawaratan Hakim ( RPH )

3. Pemeriksaan pendahuluan oleh panel hakim.

4. Pemeriksaan di persidangan dan pembuktian

5. Rapat permusyawaratan hakim ( RPH )

6. Putusan dapat berupa Mahkamah Konstitusi menyatakan permohonan:

- Tidak dapat diterima

- Ditolak 
- Membenarkan pendapat Dewan Perwakilan Rakyat jika putusan Mahkamah Konstitusi membenarkan pendapat Dewan Perwakilan Rakyat, Maka Dewan Perwakilan Rakyat akan meneruskan ke Majelis Permusyawaratan Rakyat atau Dalam hal Presiden dan/ Wakil Presiden mengundurkan diri pada saat proses persidangan di Mahkamah Konstitusi, proses persidangan di hentikan dan permohonan dinyatakan gugur oleh Mahkamah Konstitusi.

\section{Akibat Putusan Hukum Mahkamah Konstitusi atas Permohonan DPR}

Ada beberapa kemungkinan jika putusan Mahkamah Konstitusi yang mengabulkan permohonan DPR jika Presiden telah terbukti melakukan pelanggaran hukum paling tidak ada dua kemungkinan berdasarkan Undang-Undang Dasar Negara Republik Indonesia tahun 1945 yakni Pertama, Presiden dan/Wakil Presiden akan menghadapi pengadian politik di depan sidang istimewa Majelis Permusyawaratan Rakyat yang diadakan khusus untuk meminta pertanggung jawaban presiden dan wakil presiden. Kedua, Presiden dan Wakil Presiden akan menghadapi tuntutan di depan peradilan umum baik terkait tuntutan pidana maupun tuntutan hukum lainnya.

Putusan Mahkamah Konstitusi ini tidak dapat diajukan banding dan bersifat mengikat sehingga apapun putusan Mahkamah Konstitusi dan semua elemen bangsa harus menghormati dan melaksanakannya. Kemudian, akibat selanjutnya jika dalam putusan Mahkamah Konstitusi membuktikan jika Presiden dan Wakil Presiden tidak terbukti melakukan pelangaran hukum. tentu di dalam teori hukum pidana terdapat istilah ganti kerugian yang dimana hak seseorang untuk mendapat rehabilitasi atas tuntutannya berupa imbalan sejumlah uang karena ditangkap dituntut, ataupun diadili tanpa alasan yang berdasarkan Undang-Undang atau karena kekeliruan mengenai orangnya atau hukumnya yang diterapkan menurut cara yang diatur dalam KUHAP (Zoelva, 2005). Lalu bagaimana dengan putusan Mahkamah Konstitusi yang menyatakan bahwa Presiden dan Wakil Presiden tidak terbukti melakukan pelanggaran hukum, pasca amandemen tidak mengatur secara eksplisit, akan tetapi jika melihat UU MD3 pasal 215 yang dimana putusan Mahkamah Konstitusi memutuskan bahwa pendapat DPR tidak terbukti maka prosesnya tidak dapat dilanjutkan. Hal ini karena putusan Mahkamah Konstitusi tersebut menciptakan atau meniadakan satu keadaan hukum atau membentuk hukum baru sebagai negative legislator. Maka Putusan Mahkamah Konstitusi tersebut final, mengikat dan harus diumumkan dalam berita negara dalam tempo waktu paling lambat 30 hari sejak putusan diucapkan.

\section{SIMPULAN DAN SARAN}

Dari pembahasan di atas dapat disimpulkan bahwa pada masa lalu, sebelum reformasi, kekuasaan sangat besar dan tersentralisasi sehingga melahirkan suatu pemerintahan yang tidak demokratis, serta proses impeachment Presiden menggunakan alasan politis daripada alasan yuridis. Akan tetapi pasca era reformasi pengaturan tersebut pun diperjelas dengan perubahan ketiga Undang-Undang Dasar1945 ini melahirkan lembaga baru yakni Mahkamah Konstitusi, otomatis Impeachment pasca reformasi kali ini harus melalui lembaga hukum baru setelah itu lembaga politik. Kemudian, melalui penelitian ini diharapkan kepada lembaga penegak hukum supaya menyiarkan ke media mengenai putusan apapun agar publik tidak menaruh rasa curiga terhadap proses impeachment Presiden nantinya.

\section{DAFTAR PUSTAKA}

Anwar, C. (1999). Konstitusi dan Kelembagaan Negara. Jakarta: CV. Novindo Pustaka Mandiri.

Darmodiharjo, D. (1985). Santiaji Pancasila: Suatu Tinjauan Filosofis, Historis dan Yuridis. Jakarta: Kurnia Esa.

Diantha, I. M. P. (1998). Tiga Tipe Pokok Sistem Pemerintahan dalam Demokrasi Modern. Bandung: Abardin. Manan, B. (2003). Lembaga Kepresidenan. Yogyakarta: FH UII Press.

Mertokusumo, S. (2018). Mengenal Hukum: Suatu Pengantar. Jakarta: Cahaya Atma.

Soimin. (2009). Impeachment Presiden dan Wakil Presiden di Indonesia. Yogyakarta: UII Press.

Zoelva, H. (2005). Impeachment Presiden Alasan Tindak Pidana Pemberhentian Presiden menurut UUD 1945. Jakarta: Konstitusi Press.

Undang-Undang Dasar Negara Republik Indonesia Tahun 1945.

Undang-Undang No 24 Tahun 2003 Tentang Mahkamah Konstitusi. 